\title{
経管栄養と脂質代謝 一脳卒中患者の経管栄養も含めて一
}

\author{
福 生 吉 裕 \\ 日本医科大学第二内科（干102 東京都干代田区飯田橋 3-5-5)
}

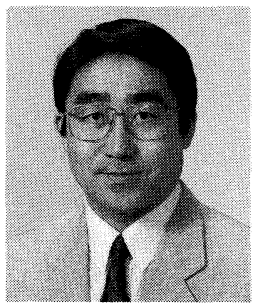

Tubal Alimentation and Lipid Metabolism

Including the Procedure of Alimentation on Patients with

Cerebrovascular Disorders

Yoshihiro FUKUO

2nd Dept of Int. Med., Nippon Medical School

(3-5-5, Iidabashi, Chiyoda-ku, Tokyo, ₹102)

In today's Japan, there are approximately 200 thousand patients with post-apoplexy were treated under the tubal alimentation. However there are few suitable tubal alimentation which could be rectify to prevent the recurrence of stroke by decreasing several risk factors. Form these points, major controllable risk factors (lipoprotein metabolism, fatty acid contents and platelet aggregation activity) of several tubal alimentations were thoroughtly discussed.

\section{はじめに}

臨床栄養学が新しい医療分野として飛躍的に進歩を遂 げたのは, 静脈的高カロリ一栄養 parenteral hyperalimentation)と経腸的高力ロリー栄養(enteral hyper -alimentation) の開発によるところが大きい。その安 全性と効果が注目を浴びている経管栄養剤について長期 使用時における生体脂質への影響について述べる。まず この経管栄養法はアポロ計画が行われた 1970 年に, 宇 由食〔低残さ(椬)食〕として一躍注目を浴びた。それま でにも, Greenstein ${ }^{1)} ら$ (1957 年)により既に chemically defined diet (化学的既成食) として開発が進め られていたものである。これらの特色は今までの経管栄 養であれば下痢などの副作用のためせいぜい $1,500 \mathrm{kcal}$ 程度しか投与できなかったのに対して, 持続的に 2,000 〜3,000 kcal を投与できる所にある。この高カロリーの 投与法は, 外科領域において, 術後の縫合不全による合 併症や，低栄養状態にあるがん(癌)患者の手術成績に著 しい改善を認めたのである。この高カロリーが投与でき る事で著しく治療法自体も改革され, 臨床栄養として新 しく独立された分野に成長をしたのである。

さてこの様にひろい分野で進歩を遂げた経管栄養であ るが, 病態別としてみた場合若干の問題点もあり,また 栄養食品のカテゴリーから抜け出せない分野も多く今後
の更なる改良が望まれる分野でもある。今回, 長期経管 栄湌と生体脂質代謝について述べると共に, 脳血管障害 患者に対する長期経管栄養法の問題点についても, 若干 の自験例を踏まえ検討を加えてみる事とする。

\section{1）経管栄䓹の種類と組成}

当初, 経管栄養剤は消化機能低下状態に陥って強制的 な栄養管理を必要とする患者に投与することを目的に作 られた。よってその対象となる疾患は，これまで外科手 術前後における補助栄湌管理としての意味合いが強かっ たように思われる。この様な条件下で作られた経管栄湌 剂として，その形態は大きく分けて，3つに分けられ る。すなわち a) 自然食品流動食, b) 半消化態栄養剤, c) 成分栄養剤である。

これらについて初めに概説をする。

a）自然食品流動食

一般に各病院栄養課で独自に作られている経管栄養剤 であり, 普通流動食, ミキサー食, 濃厚流動食に分かれ ている。これらの素材は, 牛乳, 卵黄, 果汁, 重湯など がその主成分である。カロリーの補給はせいぜい 1,200 kcal までであり, 高カロリ一の補充は望めない。ミキ

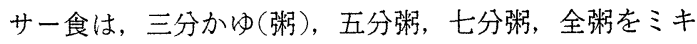
サーで流動食にしたものである。 $1,800 \mathrm{kcal} / \mathrm{d}$ 当たり まで投与できるが, 繊維質が多く含まれるため, チュー ブの目詰まりを生じやすい。濃厚流動食は, $1 \mathrm{kcal} / \mathrm{mL}$ 
以上の栄養素を含むことができる。主にチューブで行わ れる場合が多く, しかし速度の調節が難しく，ために， 早過ぎると悪心, おう(嘔)吐, 腹部膨満, 下痢などが生 じやすい欠点がある。遅いと目詰まりを生じやすい。

b) 半消化態栄養剂

低残渣食よも言われ，これまでの天然流動食よりも消 化しやすいように人工的に処理を加えた栄湌剤である。 現在市販のものが十数種開発されており，その成分は幾 分相違がある。最初のものは昭和 27 年ころ, 木村ら ${ }^{2)}$ により開発がなされた。窒素源が, タンパク質である所 が特徵である。このほかに, 糖分, 脂肪, 電解質, 微量 元素, ビ夕ミンが調節されて含まれている。カロリーは $2,000 \mathrm{kcal}$ ぐらいまであげられ, 長期経管栄養剤として の条件をそなえる一方, 夕ンパク質, 脂肪は最終段階ま で分解されずに残っている。このものは普通食に近い栄 養効果が得られるので, 食道癌のような上部消化管に通 過障害を生じた疾患には適している。一方, 消化吸収能 の低下した疾患には困難で, 下痢なども生じやすい欠点 がある。また水溶性であるが, 細いチューブ（内径 1 $\mathrm{mm}$ ）は目詰まりを起こす。高カロリ一栄養を行うには 下痢の発生のため比較的困難であり経腸的高カロリ一栄 養を必要とする疾患〔縫合不全, 消化管外万う(㾞)〕に
は不向きであろう。

現在市販の半消化態栄養剤としては, クリニミール, ハイネックス R $(\mathrm{SF})$, ニューメディエフ, ベスビオン などが知られている。

c）成分栄養剂

構成の特色はアミノ酸が主体であり, ブドウ糖, 各種 ビタミン, ミネラルよりなり, 各種栄養の基本的な, し かも化学的に明確な成分より成り立っている。消化酵素 を必要とせず, 最終段階まで分解される栄養剤である。 chemically defined diet とも言われ，また宇宙食と して低残椬食に用いられた事, 経腸的高カロリー栄湌 $(4,000 \mathrm{kcal})$ が可能な点, 消化機能障害の患者にも使用 ができる事より外科治療で注目を浴びた栄養剤である。 しかも摂取量の調整が正確にでき同一組成の食事を作る ことが可能なため, また排便量, 排便回数が少なくてす む事より，オムツを使用する脳卒中患者の管理に広く使 われ出されている。

我が国で開発された成分栄養剤にエレンタール (ED) がある。表一1に現在市販されているおもな経管食の組 成を示す。それぞれの組成, カロリ一, 脂肪量も違うた め，長期にわたって使用する場合は疾患に適した経管剤 を選ぶ必要がある。

表-1 各種経管半消化態栄養剤及び成分栄養剤の組成 (100 g 当たり)

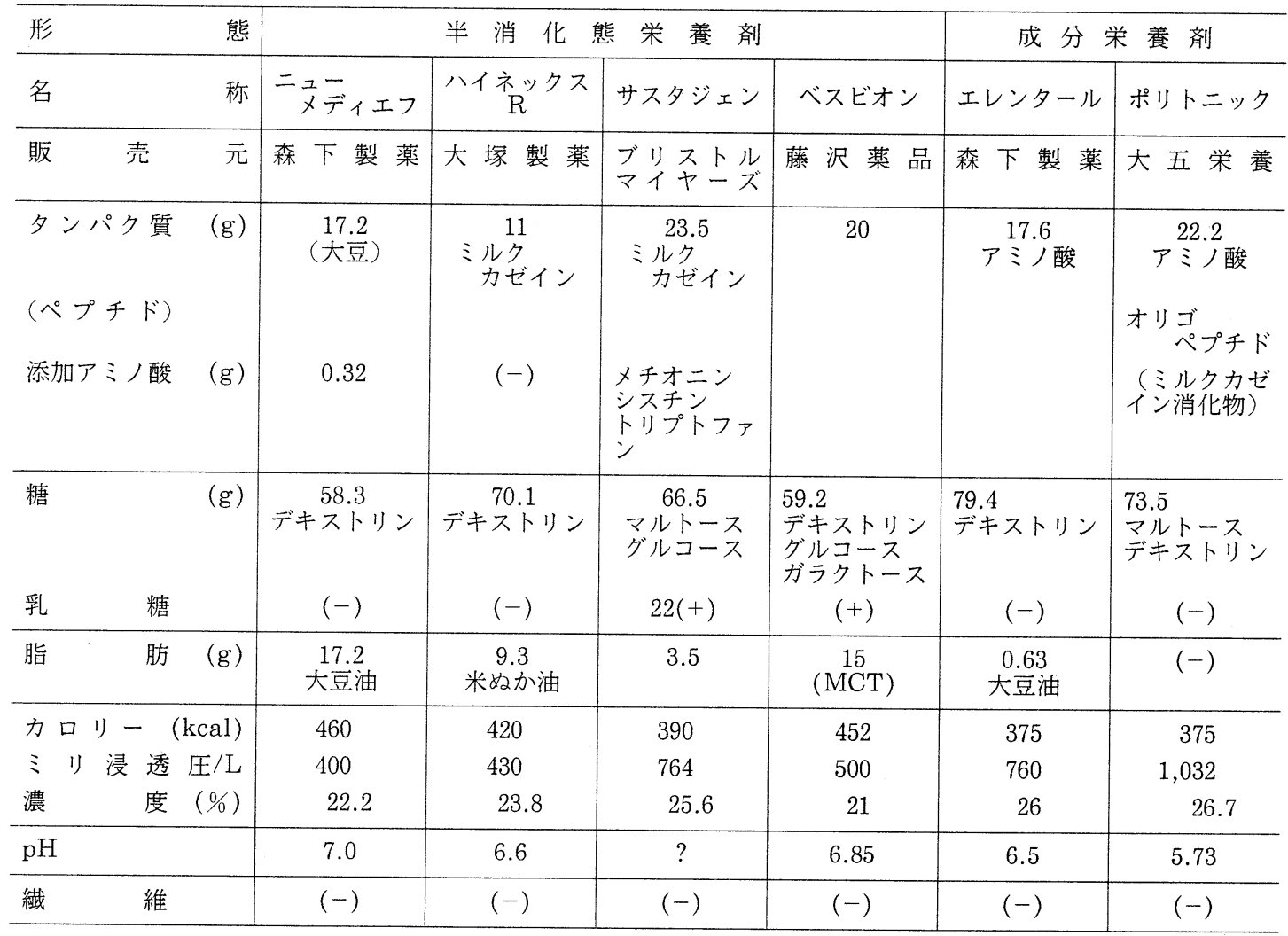




\section{2）経管栄養剂における脂肪の吸収と代謝経路}

成分栄養剂を除いた流動食中の脂肪は，大部分中性脂 肪の形で存在しており, それを構成する脂肪酸は炭素原 子数が 14 個以上の長鎖脂肪酸 $\left(\mathrm{C}_{14 \sim 18}\right)$ の形である（図 -1 a)。摂取された脂肪はそのままでは吸収されず, 胆 汁酸によるミセル形成が必要である。このミセルにすい (膵)リパーゼが作用することで, 長鎖脂肪酸のトリアシ ルグリセリンは $1 \mathrm{~mol}$ の $\beta$-モノアシルグリセリン $(\mathrm{MG})$ と $2 \mathrm{~mol}$ の脂肪酸, または $3 \mathrm{~mol}$ の脂肪酸とグ リセリンに分解され, 小腸粘膜より吸収される。細胞内 に入った $\mathrm{MG}$ と $2 \mathrm{~mol}$ の脂肪酸は小胞体上部の胞体膜 を通り内こう(腔)に達すると, 小胞体膜に存在する $\mathrm{TG}$ 合成酵素により再び TG に合成されて, コレステロー ル, アポタンパク (apo B 48, apo A-I, apo A-IV),

リン脂質とキロミクロンを形成し, リンパ管, 胸管を経 て, 全身循環に入る。そこではリポタンパクと結合し very low density lipoprotein (VLDL) の形で存在し ている。また中鎖脂肪酸 $\left(\mathrm{C}_{6 \sim 10}\right)$ は, 膵リパーゼが存 在しなくても小腸粘膜内のリパーゼで分解を受けそのま
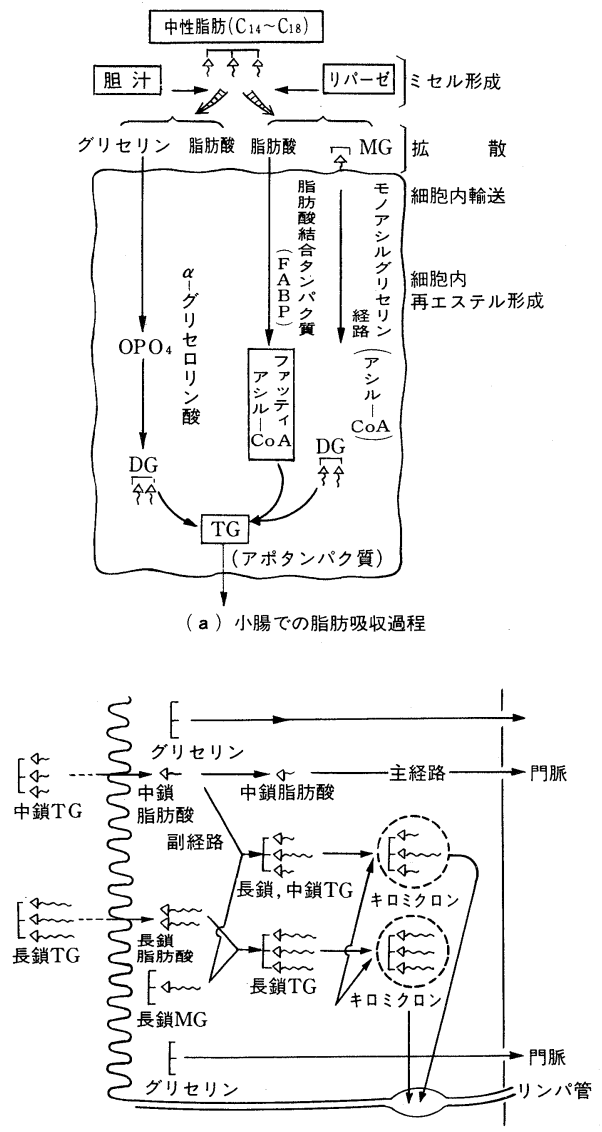

（b）中鎖脂肪酸のリンパ管輸送の機序

図-1 脂肪の吸収
ま容易に吸収され，再エステル化を受けることなく遊離 脂肪酸の形で, 腸粘膜内を移動し, 直接門脈から吸収さ れ肝にいたる。(図一-1 b) に，中鎖脂肪酸の消化吸収経 路を示した。この中鎖脂肪酸を脂肪の $56 \%$ 成分として 取り入れた経管栄湌剤にベスビオン $(\mathrm{BV})$ がある。胃 内でのエマルション形成が容易なためとリパーゼによる 消化が容易なため，また胆汁酸によるミセル形成不要な ため, 胃切除後症候群, 慢性膵疾患, 胆のう(囊)症吸収 不良症候群には適している。各種半消化態経管栄養剤の 脂肪構成は表-1に示してある。それぞれ相違があるた め長期にわたって使用する場合はその特徴を知っておく 必要がある。

\section{3）長期経管栄養上必須脂肪酸}

自然食品流動食が使用されている間は特に問題が起こ らないが, 長期に渡り IVH や成分栄養剤が使用される 場合は必須脂肪酸の問題は重要である。この必須脂肪酸 の重要性は1930 年にBurr 夫妻 ${ }^{3)}$ が無脂肪食をラット に与えた実験により明らかにされたものである。欠乏に より多彩な症状〔成長の延長, 皮膚炎, じん(腎)障害〕 が生じる事が認められた。このことより, 体内では合成 されない脂肪酸があることが証明され, 主にリノール酸 の欠乏に因るとして，これを必須脂肪酸と呼ぶこに なった。このリノール酸の一日の必要量は約 $7.5 \mathrm{~g}$ ある いは, 総力ロリーの 4\% は摂取が必要とされている 臨床面において, 実際無脂肪 IVH, や経管栄湌のみで あると, リノール酸は 3 日目には $1 / 3,10$ 日目には $1 / 6$ に減少することが報告されている5゙。このリノール酸は n-6 系であるため, アラキドン酸へ上 chain elongation を受けて変換されていく(図一2)。

アラキドン酸は血小板凝集能こう(元)進作用を持つト ロンボキサン $\mathrm{A}_{2}$ の母体でもあるが, リノール酸が欠乏 状態であると, アラキドン酸の代わりに，イコサトリエ ン酸 $\left(\mathrm{C}_{20: 3, n-9}\right)$ を生産するようになる ${ }^{5}$ (図一 3 )。これ はリノール酸の量が少なくなると, 酵素系が代わりに生 体内で合成されるオレイン酸 $\left(\mathrm{C}_{18: 1, n-9}\right)$ に作用しイコ
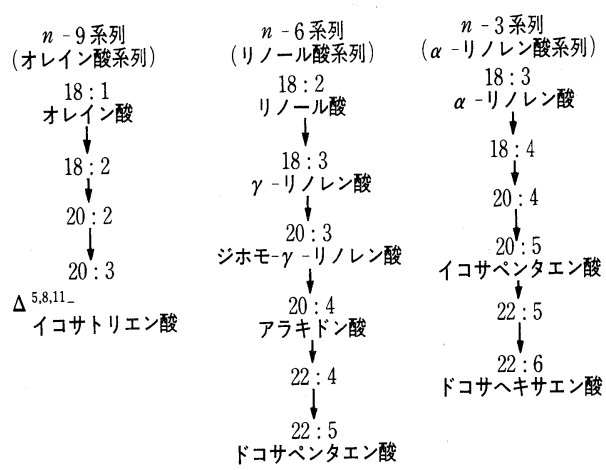

図-2 高度不飽和脂肪酸とその体内代謝過程 


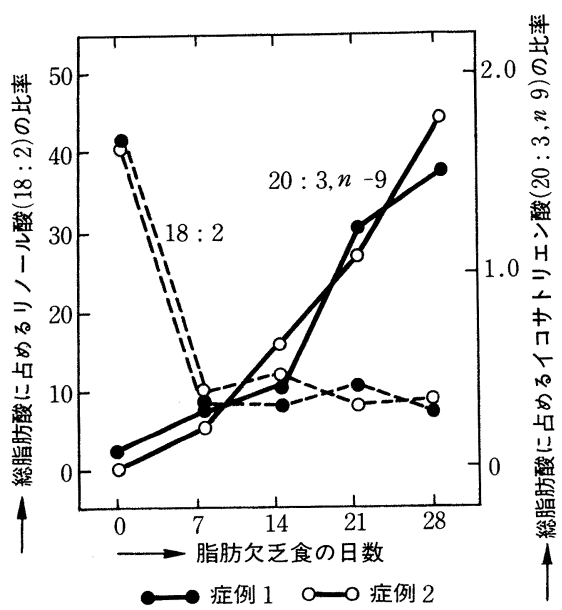

図-3 健康人における必須脂肪酸欠乏の出現速度 （経口栄養及び静脈栄養）

サトリエン酸を産生するからである。このイコサトリエ ン酸が上昇するとアラキドン酸よりもより強く細胞障害 性に作用することになる。臨床的にはまず血小板凝集能 抑制作用を生じ6)，未熟児において出血傾向を生じやす い7。また肺では, surfactant の成分であるホスファ チジルコリンに障害をもたらし，ショック肺に陥らせや すくなる ${ }^{8)}$ 。またプロスタグランディン系に障害を及ぼ す。さらに乳児においては必須脂肪酸欠乏は脳の発育に 多大の影響を与えることが報告されている ${ }^{9)}$ 。この様に 必須脂肪酸は色々な臓器において重要な役割を担ってい ると言える。また必須脂肪酸欠之状況はカロリーと密接 な関係を有し, 低カロリー状態であると生じにくく, 逆 に高力ロリー状態では必須脂肪酸欠乏状態が引き起こさ れやすい10)。この事はカロリー不足であると貯蔵脂肪 中のトリアシルグリセリンから, 組織内リパーゼにより 脂肪酸が遊離動員され, 肝臓で利用されるのに対して高 カロリーが投与されると, 糖質過剩のため高インスリン 血症となり脂肪組織よりリノール酸の動員がスムーズに 行かなくなり，リノール酸の低下が生じるとされてい る。

この必須脂肪酸欠乏状態の改善には, リノール酸の補 充を行えば良いのであるが, その目安は, 総力ロリーの
2.5 4\% とされている。長期経管栄湌剤の投与に当 たって注意しなければならない所であるが, 現在市販の 半消化態栄養剤であればまず欠乏状態は起こらない。成 分栄養剤 (エレンタール) の場合は, 脂肪成分が 0.6 $\mathrm{g} / 100 \mathrm{~g}$ 亡低いため必須脂肪酸欠乏状態に注意しなけれ ばならない。その対策として $10 \%$ 経静脈的脂肪製剂の 併用が推奨されている。

4）各種経管栄養剂の脂質代謝への影響

a) 動物実験における経管栄養剤の検討

各種経管栄養剤の代謝についてこれまで行われた動物 実験による検討から見ていくことにする。

浜野ら ${ }^{11)}$ はラットを用いて, SF (ハイネックス R) と $\mathrm{ED}$ (エレンタール) を 2 週間投与し肝臓内の脂肪酸 組成について検討を行っている。これによると, 肝蔵内 TG 量は, SF, ED 両群でも普通食群に比べ高値を示し たが，その増加率は， $1.5 \%$ の低脂肪食である ED の方 が，脂肪を $24.4 \%$ 含む $\mathrm{SF}$ より高かった（表一2）。この 実験から認められるように, 生体の眝蔵脂肪 (deposit fat）は低脂肪の方が, 高脂肪投与より増加する。この ことは, 炭水化物, タンパク質から脂肪への転換が行わ れている事で, Acetyl CoA への degradation が低脂 肪食の場合, 他の栄養素から優先的に行われることを示 唆している。また脂肪酸組成にも変化が見られ, ミリス チン酸, パルミチン酸, パルミトレイン酸, ステアリン 酸, オレイン酸など増加が見られるのに対し, リノール 酸の減少が見られている。肝グリコーゲン量は, EDで は極端に低下を示している。これは肝における脂質代謝 の変化のために肝のグリコーゲン産生に抑制が生じたも のと考えられる。

なお EDに $10 \%$ 及び $20 \%$ の脂肪を補うと肝グリ コーゲン量の増加が見られ, 肝 TG 量の上昇が抑制さ れ逆に減少が生じることが認められた。

肝臓内での内因性脂肪合成はフィードバック機構で調 整されているため, 消化管の intactな生体の場合, 極 端な低脂肪食が投与されると lipogenesis がえ進され る。一般のヒトの場合総熱量の 20〜25\%を脂肪で取れ ばこれらの代謝変化を来たさないので, 低脂肪食を長期 に取る場合はその適応を考えるべきであろう。逆に消化 器系を女静にさせなければならない膵炎や, 腸瘦の場合

表-2 ラットに打けるハイネックス R及びエレンタール投与後の筋窒素, 肝トリアシルグリセリン, 肝グリコーゲンの変化 $(\mathrm{mg} / \mathrm{g})^{11}$

\begin{tabular}{|c|c|c|c|c|c|}
\hline & \multirow{2}{*}{$\begin{array}{l}\text { 対 照 } \\
\text { (普通食) }\end{array}$} & \multirow{2}{*}{$\begin{array}{l}\text { ハイ } \\
\text { ネックス R } \\
\text { SF } 1003\end{array}$} & \multicolumn{3}{|c|}{ エレンタール $(\mathrm{ED}-\mathrm{AC})$} \\
\hline & & & 脂肪無添加 & 脂肪 $10 \%$ & 脂肪 $20 \%$ \\
\hline 筋 窒 素 & $27.4 \pm 4.7$ & $27.5 \pm 4.5$ & $25.9 \pm 4.7$ & $20.4 \pm 1.7$ & $20.0 \pm 0.8$ \\
\hline $\begin{array}{l}\text { 肝トリアシル } \\
\text { グリセリン }\end{array}$ & $3.5 \pm 2.3$ & $19.5 \pm 13.9$ & $43.9 \pm 32.3$ & $6.7 \pm 3.0$ & $3.6 \pm 1.0$ \\
\hline 肝グリコーゲン & $18.6 \pm 15.5$ & $23.2 \pm 19.9$ & $9.1 \pm 7.4$ & $37.0 \pm 23.2$ & $32.3 \pm 4.1$ \\
\hline
\end{tabular}


は低脂肪の適応となる。

b) 臨床例による検討

投与された生体側の条件にもよるが，これまで報告さ 机た臨床例による経管栄養剤の血中脂質代謝に及ぼす影 響については，以下のようにまとめる事ができよう。

1）生体脂質にほとんど影響を与えないもの。 ベスビオン（ただし $\mathrm{T}-\mathrm{cho}$ ), クリニミール

2）血中脂質を下げるもの。 エレンタール（ただし T-cho）

3）血中脂質を上昇させるもの。 ハイネックス $\mathrm{R}$, ベスビオン（ただし $\mathrm{T}-\mathrm{G}$ ), ニューメディエフ, エレンタール（ただし $\mathrm{T}$ G)

エレンタールは膵炎, かいよう (潰瘍) 性大腸 炎, Crohn 病, 腸瘦などの消化管の安静が必要な疾患に用 いられる事をその目的にして作られているため，消化酵 素の膵リパーゼ，亡胆汁酸の分泌を抑制させるために長 鎖脂肪酸を極端に制限している。エレンタール $80 \mathrm{~g}$ 中 の脂肪は大豆油にして $0.53 \mathrm{~g}$ しか含まれていないため, $2,000 \mathrm{kcal}$ が投与されたとしてもリノール酸にして約 $1.8 \mathrm{~g} / \mathrm{d}$ の摂取しかない。一日の必要摄取量が $7.5 \mathrm{~g}$ な ので長期にわたれば欠乏状態が生じる。消化管手術後に エレンタール $1,500 \mathrm{kcal}$ を投与し 10 日目, 20 日目に血

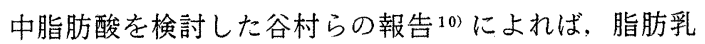
剂を静脈的に補充してないと, 投与 10 日目にしてリ ノール酸は $1 / 2$ に減少し, $\mathrm{C}_{20: 3, n-9}$ (イコサトリエン 酸), $\mathrm{C}_{16: 1}$ (パルミトオレイン酸), $\mathrm{C}_{18: 1}$ (オレイン 酸）の上昇が見られたとしている。20\%脂肪乳剤を投 与された群はその様な反応は見られなかったとしてい る。このような報告より, エレンタールの単独投与で は, リノール酸の欠乏状態が生じる恐れがあるため, こ の予防として, 脂肪酸の静脈投与が必要亡なる。この適 用量は $10 \%$ 大豆製剂にして，一日 $150 \mathrm{~mL}$ 程度とされ る。大豆油には $50 \%$ のリノール酸が含まれているため, $150 \mathrm{~mL}$ であると $7.5 \mathrm{~g}$ のリノール酸が供給され, 必要 量を充たすことになる。この脂肪乳剂として現在使用さ れているのにイントラリピッド, イントラファット，イ ントラリポスなどがある。

\section{5）脳卒中と長期経管栄䓹}

近年, 寝たきり脳卒中患者が急速に長期経管栄養の対 象にあげられてきており，在宅寝たきり患者への経管栄 養の対策が求められてきている。現在寝たきり脳卒中患 者は, 全国で 60 万人, その内経管栄養を必要とする患 者は約 20 万人強いる（昭和 61 年国民生活基礎調査, 厚 生省) と見られ，この数はこれからも増える可能性は多 大にあり，その需要は增加してきている。しかもその経 管栄養使用機関は, 数か月から数年に及ぶ場合が多く, 半永久的でもあるため, 長期経管栄養剤の脳血管障害患
者に対する影響については，再発予防の面からも重要な 関心事之なってきている。この章では, 脳卒中者におけ る長期経管栄養の脂質代謝, ことに脂肪酸への影響につ いて検討を加えてみる。さらに脳卒中患者を対象とした 理想的経管栄養に付いて我々の研究の一端を述べる。

a）経管栄養剂より見た脳卒中という病態。

再発頻度は 2 年間に $20 \%$ 前後之報告されており ${ }^{12)}$, 少なくはない。そのタイプ別で見ると再発が脳出血であ るのは漸隇傾向を示しているか脳こうそく(梗塞)は逆に 増加傾向にある ${ }^{13)}$ 。このことは脳出血タイプの再発に おけるリスクファクターである血圧の管理は広く認識さ れその成果が出てきたものと考えられるが，しかし脳梗 塞タイプの再発が依然低下しないのはその予防に関して の対応が充分になされていないものと考えられる。塩分 摃取の制限については既に実践されていて, 再発の夕イ プが圧倒的に出血よりも梗塞が多くなっている事からも うかがえる。すなわち脳卒中者用の経管栄養剤として今 後必要なのは梗塞性再発をいかに抑えるかにあると言っ ても過言ではない。

b) 脳卒中再発のリスクファクターとしての脂質と 脂肪酸

著者らは一たん脳梗塞を生じた患者 184 名において再 発のリスクファクターについて血中脂質代謝面より 2 年 間の検討を行った結果, 脳卒中発症後 HDL コレステ ロールが低下することが新たな再発を誘導するファク

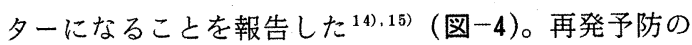
栄養管理の目安として, この HDL コレステロールを低 下させないことは必要なことの条件に成りうると考えら れる。
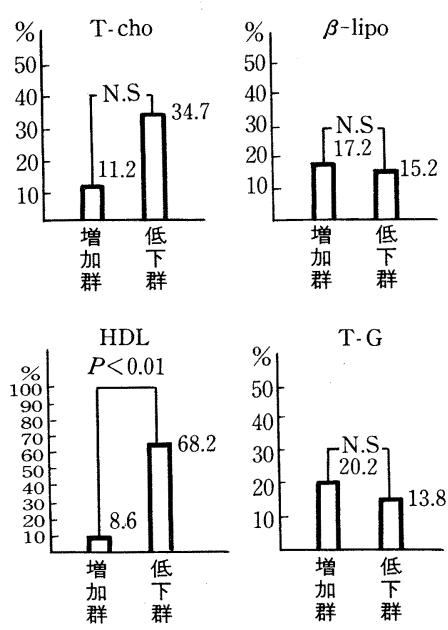

HDL 低下群で再発が多いことを示している

図-4 脳卒中再発群における Retrospective な検討 （初発後 2 か月目での脂質変化） 
次に脂肪酸に関して述べる。 $n-3$ の EPA は血小板凝 集能抑制効果を示すと同時に脂質低下作用も有し，その 多量摂取者における心筋梗塞, 脳卒中の発生率はコント ロール群に比べ有意に少ない。これらの $n-3$ 系 $\mathrm{EPA}$ は $n-6$ 系アラキドン酸由来のトロンボキサン $\mathrm{A}_{2}$ の合 成を抑制すること，脂質代謝に関しては Cho, TG の低 下作用を有することより動脈硬化抑制作用を示すことな ど, 間接的に脳卒中の予防作用を発揮するとされてい る。脳梗塞を穿通枝梗塞之皮質枝梗塞に分けてその脂肪 酸組成を見た成績では, パルミチン酸が高く, リノール 酸が低い傾向がごちらも出ている ${ }^{16)}$ 。このことは赤血 球の膜の構成成分に変化をもたらし流動性に影響を与え る。すなわち, リノール酸が低下し, パルミチン酸が上 昇すると赤血球変形能が低下すると考えられている。ま た血小板凝集能と脂肪酸組成を検討した成績では, リ ノール酸上パルミチン酸はよ゙ちらも血小板凝集能には影 響を及ぼしていない成績も出ている ${ }^{17)}$ 。一方血小板凝 集能穴進例では, アラキドン酸含有量が低く, 逆に EP A 含量が高い結果であった。この事は一見矛盾する結 果であるが, 脳卒中発生後という環境である事を考慮 し，検討を加えなければならない事柄であろう。すなわ ち脳卒中発生後という環境では血中脂肪酸の血小板凝集 能への反応性が低下していることを示唆している。これ らの検討より経管栄養剤の含有脂肪酸組成も今後重要な 意味を持つものと示唆される。

さてこ扎まで市販の経管食 $(\mathrm{N}-\mathrm{MF}, \mathrm{ED}-\mathrm{AC})$ で, 寝たきり脳卒中患者での血中脂質, 脂肪酸, 凝固線溶系 への影響を調べた。その結果, 院内流動食と, N-MF は T-cho, $\beta$-lipoの上昇を認め, $\mathrm{ED}-\mathrm{AC}$ は著しい HDL-cho の低下を認めた ${ }^{18), 19)}$ (図-5)。いずれもA， Iには改善をもたらさず長期に渡って経管栄養を行うこ 之は動脈硬化の進展を助長する可能性が示唆された。脂 肪酸においては, 長期経管栄養者では, EPA, DHA,リ ノレン酸に著明な低值を認めた。血液凝固系では, 長期 経管栄湌者はフィブリノーゲンが高く, AT- III, PLG, Protein $\mathrm{C}$ 抗原量は有意の低值を示した。これらの事 は, 現在の市販の経管栄養では血液脂質及び血液凝固系 より動脈硬化促進的に作用されることが推測される。

c）脳卒中患者のための経管栄養剤とは
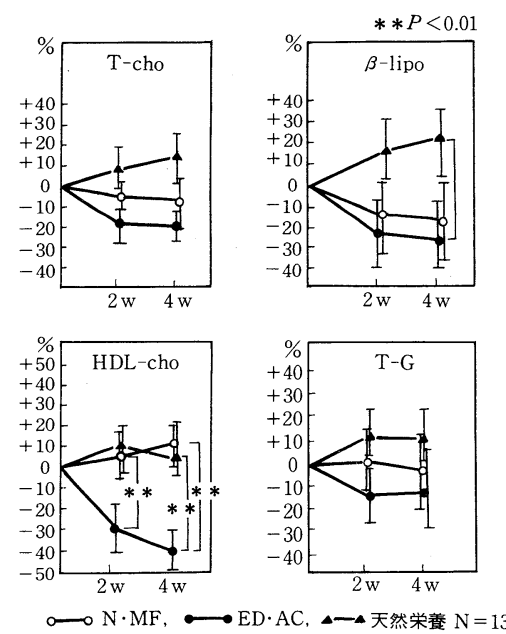

図一5 各種経管栄養剤の脂質代謝に及ぼす影響

これらの検討より経管栄養剤についてみると, そのポ イントは, いかに血小板凝集能抑制と, HDL-choの上 昇を図るかにあると思われる。以下に脳卒中再発予防の ための理想的経管栄養剤の条件を記した。

(1) 体液 (タンパク質, 電解質, 微量金属, ビタミン 類, 血糖）のアンバランスを来たさないもの。

(2) 下痢，嘔吐の少ないもの

（3）易消化性，易吸収性のもの

(4) 経済的に安価

(5) 血液凝固能の亢進を来たさないもの

(6) HD コレステロールの低下を来たさないもの

d) 試作経管栄養剤の検討

我々はこれらの指標を基に新たに経管栄養剤を調製し てその効果についてこれまで検討を加えたのでここでは その要旨を述べる。

(1) PUFA リッチ経管栄養剂の場合 ${ }^{15)}$

食事から摂取する高度不飽和脂肪酸之飽和脂肪酸の比 の変化が血中コレステロール值や血液凝固因子に影響を 与えることが古くから知られている。Keys, Hegsted らは血清コレステロールの上昇率を高度不飽和脂肪酸と 飽和脂肪酸との摂取量比 $(\mathrm{P} / \mathrm{S})$ から割り出せることを 計算式で示し, スウェーデンの Vessby らは高脂血症

表-3 高度不飽和脂肪酸リッチ (P/S 2.0) 食の血中脂質に与える影響 (6か月間経管栄養患者での検討結果)

\begin{tabular}{|c|c|c|c|c|c|}
\hline P/S 比 & $\begin{array}{l}\text { 総コレステ } \\
\text { ロール } \\
(\mathrm{mg} / \mathrm{dL})\end{array}$ & $\begin{array}{l}\text { トリアシル } \\
\text { グリセリン } \\
(\mathrm{mg} / \mathrm{dL})\end{array}$ & $\begin{array}{l}\beta \text { タリポ } \\
\text { タンパク質 } \\
(\mathrm{mg} / \mathrm{dL})\end{array}$ & $\begin{array}{l}\mathrm{HDL}-コ レ \\
\text { ステロール } \\
(\mathrm{mg} / \mathrm{dL})\end{array}$ & $\begin{array}{c}\text { 動脈硬化指数 } \\
(\mathrm{AI})\end{array}$ \\
\hline $0.2(n=11)$ & $226 \pm 43$ & $111 \pm 40$ & $367 \pm 119$ & $41 \pm 6$ & $4.39 \pm 0.4$ \\
\hline $2.0(n=11)$ & $189 \pm 65^{*}$ & $94 \pm 37^{\mathrm{ns}}$ & $329 \pm 98^{\mathrm{ns}}$ & $47 \pm 11.3^{* *}$ & $3.2 \pm 0.3^{* * *}$ \\
\hline
\end{tabular}

注) Paired t-test. $* p<0.05, * * p<0.01, * * * p<0.001, \mathrm{~ns}=$ no significant. 
患者の食事内容を $\mathrm{P} / \mathrm{S}$ 比を 0.2 から 2.0 に変化させる と LDL コレステロール値が $10 \%$ 前後低下することを 報告している。我々も経管栄養食において $\mathrm{P} / \mathrm{S}$ 比を 1.7 ～2.0 と高度不飽和脂肪酸 rich になるように経管栄養 剂を調節し，また PFC（タンパク質, 脂肪, 糖) 比は それぞれ $21 \%, 25 \%, 54 \%$ 亡なるように作成した。この 組成でもって 6 か月間, 寝たきり脳卒中患者に投与を行 い，血中脂質代謝，血小板凝集能への影響を検討した。 (表-3) のごとく $\mathrm{T}$-cho, $\beta$-Lipo, $\mathrm{T}-\mathrm{G}$ は $10 \%$ から $15 \%$ へ之改善し, HDL-cho は $6 \mathrm{mg} / \mathrm{dL}$ の上昇を認め た。動脈硬化指数も有意に低下が見られ，少なくとも脂 質代謝面においては動脈硬化抑制的に作用していると考 えられる。さらに血小板凝集能に対しても $71 \%$ から 27 $\%$ へと有意の低下が見られた。しかし出血時間, 凝固 系には影響をもたらさなかった。さらに血液一般，血液 生化学に対しては著変を認めず, 消化器症状に関して は, 嘔吐は無しであり, 下痢, 便秘の率も変わりは無 かった。寝たきり脳卒中患者の再発予防のための経管栄 養剤としてまずは高度不飽和脂肪酸 rich (1.7〜2.0)の 組成に保つことは必要な事と考えている。

（2）大豆タンパク質の有効性 ${ }^{20)}$

次に同疾患の 22 名を対象に $\mathrm{P} / \mathrm{S}$ 比は 1.7 に固定して おき, 大豆夕ンパク質 rich とカゼイン rich の経管食を 作成し 6 か月間投与し, 脂質代謝に及ぼす効果について 検討を行った。大豆タンパク質投与群はカゼイン投与群 に比べ $\mathrm{Ht}, \mathrm{Hb}$ の改善傾向が認められた。有意の差はで はなかったが総夕ンパク，アルブミンの上昇も認められ た。また HDL-cho 值は上昇し，アポ A I は $100 \mathrm{mg} /$ $\mathrm{dL}$ より $137 \mathrm{mg} / \mathrm{dL}$ へ上上昇し動脈硬化指数も 4.1 よ り 2.7 へ有意の低下を示した（図一6）。他に重とく(䖒) な副作用はなく，下痢，便秘の腹部症状も対照とくらべ 差はなかった。脳卒中者においても，経管栄養として $\mathrm{P} / \mathrm{S}$ 比を 1.7 に保ち大豆タンパクを加えることは脂質代 謝の改善効果が認められた。動脈硬化を基盤とした脳梗 塞患者の再発予防として栄養学的アプローチの可能性が 今後期待される。

(3) EPA 魚油の効果 ${ }^{21)}$

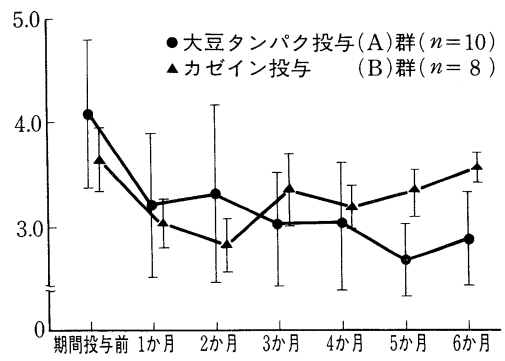

図-6 大豆タンパク及びカゼイン rich 経管食投与によ る動脈硬化指数の変化
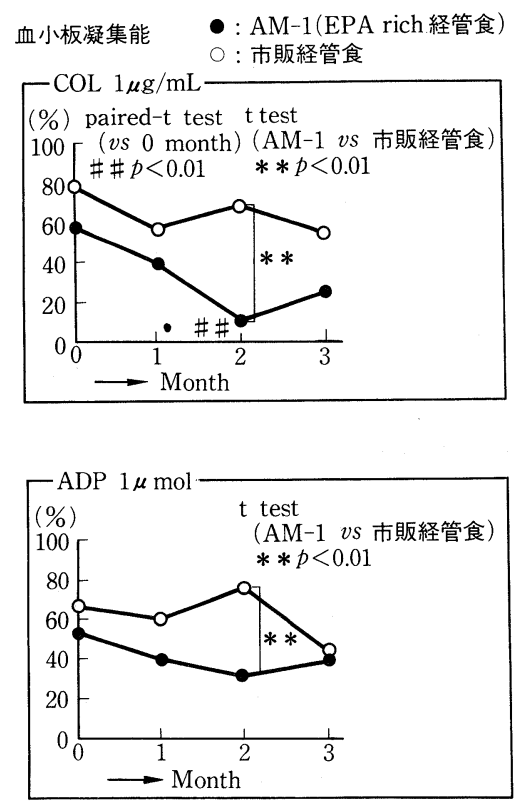

図-7 EPA rich 経管食 $(\mathrm{AM}-1)$ の脳梗塞患者の血小 板凝集能への効果

イコサペンタエン酸 (EPA) は, アラキドン酸からの トロンボキサン $\left(\mathrm{TxA}_{2}\right)$ 合成を阻害し, 一方プロスタ サイクリン $\left(\mathrm{PGI}_{3}\right)$ を形成する。この $\mathrm{PGI}_{3}$ に血小板凝 集能抑制作用があるとされる。従って, 動脈硬化の進展 予防に対しては有効之考えられている。これまでの脳血 管障害患者における市販の長期経管栄養法による血中脂 肪酸分析の結果 $n-3$ 系の著しい低下を来たすことによ る反省亡, EPA の血小板凝集能, 血中脂質代謝へ及ぼ す影響についての報告により, 脳卒中の再発予防に対し て, 血中脂肪酸 EPA 濃度の上昇は有効と考えられた。 そこでさらに，これまで二度に渡り EPA rich な経管 栄養剂を作成し，脳梗塞患者を対象にその安全性と効果 を検討した。EPA リッチ経管栄養剤を一般の市販の経 管栄養剤との比較を検討した結果を示す。EPA は $2 \mathrm{~g} / \mathrm{d}$ 追加した。 3 か月後には, 動脈硬化指数は 3 か月で 4.46 \pm 2.60 より $3.99 \pm 1.86$ に低下した。過酸化脂質の問題 が残るが, LPO 法では両群に有意の差は見られなかっ た。血小板凝集能では特に Collagen 凝集能が抑制さ れ，ADPでも凝集抑制傾向が見られた。EPA はその 血小板凝集作用ばかりでなく血清脂質代謝にも改善傾向 を示すため, 脳梗塞者の再発予防の経管栄養剤としては 効果が期待される（図一7）。

\section{おわりに}

現在用いられている経管栄養剤の問題点亡, 我々の試 作した経管栄養剤の利点と改善点を中心に生体脂質（血 中脂質代謝, 血中脂肪酸代謝) に及ぼす影響について述 
ベた。臨床栄養の分野は外科領域において急激な進歩を とげているが，まだ総て疾患別に対応されているとは言 いがたい状況である。特に寝たきり脳卒中患者への需要 は増すと考えられているが, 残念ながら適切な経管栄養 剤はいまだほとんど無いと言えよう。今後再発予防ばか りでなく痴ほう(呆)防止の経管栄養剤への試みなよ゙更に より多くの病態別にあった経管栄養剤の開発が期待され る。

\section{文献}

1) J.P. Greenstein et al., Arch. Biochem. Biophys., 72, 396 (1957)

2）木村信良, 医療, 6(2), 41 (1952)

3) G.O. Burr, M.M. Burr, J. Biol. Chem., 86, 587 (1930)

4) Committee on Nutrition, Am. Acad. Pediatrics, Pediatrics, 57, 278 (1976)

5) J.D. Wene et al., J. Clin. Invest., 56, 127 (1975)

6) M.J. Silver, J.B. Smith, C.M. Ingerman et al., Prostaglandins, 4, 863 (1975)
7) M.A. Valdes-Depena, J.B. Arey, J. Pediatr., 77, 366 (1970)

8) R. Tabata, Arch. Jpn. Chir., 48, 571 (1979)

9) Z. Freidmann, Am. J. Dis. Child, 134, 397 (1980)

10) 谷村 弘, 佐藤友信, 日笠頼則, 外科治療, 44, 4, 413 (1981)

11）浜野武史, 大柳治正, 光野孝雄, 日本静脈経腸栄養研 究会誌, 1, 14 (1986)

12）輪田順一, 上田一雄ら, 脳卒中, 15 (2), 124 (1983)

13) 神田 直, 厚生省循環器病依託研究 59-公 3,301 (1986)

14）福生吉裕, 永島幹夫ら, 臨床成人病, 14 (8), 128 (1984)

15）赫 彰郎, 福生吉裕, Pharma Medica, 5 (4) 48, (1987)

16）宮原忠夫ら, 動脈硬化, 12, 795 (1984)

17）都島基夫ら, 血液上脈管, 15, 281 (1984)

18）福生吉裕, 小林陽二ら, 日本静脈経腸栄養研究会誌, 1 , 128 (1986)

19）小林陽二, 福生吉裕ら, JJPEN, 7 (5), 851 (1986)

20) 福生吉裕, 小林陽二ら, 日本静脈経腸栄養研究会誌, 4 , 238 (1989)

21) S. Takagi, Y. Fukuo et al., Proceeding of Atherosclerosis, in press. (1991) 